\title{
Calvin, Luther and church unity
}

\author{
I.W.C. van Wyk \\ Africa Institute for Missiology \\ Reformed Theological College \\ University of Pretoria \\ PRETORIA \\ E-mail: aim1@mweb.co.za
}

\begin{abstract}
Calvin, Luther and church unity

This article deals with Luther and Calvin's efforts to preserve and promote church unity. Attention is given to their role as leaders of the reformational movement who self-evidently had to unite people from different countries. Special attention is given to Calvin's ecumenical activities. Information is given about his letters, pastoral advice and mediation efforts. Short notes are also provided on their dogmatic explications for the unity of the church.
\end{abstract}

\section{Opsomming}

\section{Calvyn, Luther en kerkeenheid}

Hierdie artikel handel oor die pogings van Luther en Calvyn om kerkeenheid te bevorder. Aandag word gegee aan hulle rol as leiers van die reformatoriese beweging wat vanselfsprekend mense uit verskillende lande moes verenig. Spesiale aandag word aan Calvyn se ekumeniese aktiwiteite gegee. Inligting word gegee oor sy briewe, pastorale adviese en bemiddelingspogings. Kort notas word ook verskaf oor hulle dogmatiese besinnings oor die eenheid van die kerk.

\section{Introduction}

In 2007, the World Alliance of Reformed Churches (WARC) identified the theme of "church unity" as one of the eight most important topics for the 2009 Calvin celebrations (cf. WARC, 2007). One is grateful to the editors of this volume for their decision to include a whole division on this theme. The continued disunity among the 
reformed churches in South Africa, calls for a revisit of Calvin's theological thinking and ecclesiastical activities.

The request of the editors for an article on Calvin and Luther should be met with realistic expectations. It is impossible to do justice to the dogmatic views on church unity of two great theologians within the space of a short article. Emphasis will therefore fall on the role of the two men during the time of dogmatic disagreements. Special attention will be given to Calvin's ecumenical activities. These activities provide us with a far better insight into his understanding of church unity than a theoretical analysis of his dogmatic view on this theme would.

One should also keep in mind that Luther was much older than Calvin and that the two reformers were, therefore, not in a position to engage in joint endeavours for the sake of the unity of the church. The two never met and were only familiar with each other's Latin writings. They also did not leave us with long systematic treatises on the unity of the church. We can identify their viewpoints on unity mostly from their reactions to the statements of their adversaries.

The importance of this theme for the Southern African region should be self-evident, as there are many painful divisions among the reformed (and Lutheran) churches in this region. A revisit of Luther and Calvin could motivate us today to do more in terms of church unity. These two reformers, Calvin in particular, set the example of a multi-angled approach to church unity. I am convinced that by emulating Calvin's multi-dimensional approach to church unity, we could initiate new initiatives that would lead to new possibilities of cooperation between the churches.

\section{The Reformation and the unity of the church}

Before coming to Luther and Calvin's ecumenical contributions and theological viewpoints, it is important to make a few remarks on the reformational movement and church unity. Firstly, one should remember that the leaders of the reformational movement, and for that matter Luther and Calvin, initially had no plans to break away from Rome. Both of them, as well as people such as Melanchthon and Zwingli, wanted to reform the Roman Catholic Church from within. The unity of Christendom was important to them. Luther never intended to start a new church, but rather to purify the one, holy church (Lohse, 1995:220-230; Concordia, 2007:57). Although Calvin called the Roman Catholic Church the "non-existent church", the "devilish faction within the church", he continued saying that she 
contained remnants (vestigia) of the one church of Christ. He kept on calling the "false church" the "mother". As a young man he even recognised the primacy of the Roman bishop by calling him the "first among equals" (primus inter pares). He therefore never pleaded for a separation or division. The unity with the church in Rome remained non-negotiable to Calvin, insisting, however, that unity should be based on biblical truths (cf. Smidt, 1972; Ganoczy, 2004:9-14). It should also be remembered that Luther and Calvin were but two theologians among many who strove to close the breach between Rome and the factions of the Reformation. The two were therefore imbedded in a climate of responsibility towards church unity. Other men, who deserve to be mentioned in this regard, are Martin Bucer and the Roman Catholic Johann Gropper, who were responsible for the Liber Ratisbonensis, the principal document laid before the Colloquy of Ratisbon (1541) that endeavoured to restore unity between the groups (Nijenhuis, 1994:25). However, it was Calvin who tirelessly worked for unity with Rome. He showed his commitment to church unity by attending the religious colloquies with Melanchthon and Bucer in Frankfurt in 1539, Hagenau in 1540, and Worms and Regensburg in 1541. In Regensburg, they managed to reach an agreement with Eck and Gropper on the themes of original sin, freedom of the will, and justification. Unfortunately, Luther and the Pope rejected the doctrinal formulation of "double justification" and the doctrine of transubstantiation, and this prevented an agreement between the parties. Secondly, one should remember that unity was an important theme among the protestants themselves. Obviously, it was of utmost importance to both Luther and Calvin. Their sense of duty towards unity was strengthened by the general attitude of loyalty and camaraderie between all people who identified with the renewal movements. Strong bonds of unity existed between not only theologians, but also between theologians and people from the other sciences who were persecuted by the authorities of the time. It should therefore be selfevident, that Luther(ans) and Calvin(ists) would have done everything possible to maintain, restore or create unity among themselves (cf. Balke, 1982; Ganoczy, 2004:3-8). One unique example to be mentioned is the first edition of Calvin's Institutio Christianae religionis (1536), which was an apology in defence of the Lutheran reformation, directed to the Emperor (Neuser, 1971:24-30).

\section{Luther, Calvin and church unity}

As already stated the two reformers never personally joined forces in efforts concerning church unity. The Consensus Tigurinus (1549), 
for instance, was only signed three years after Luther's death in 1546. Calvin never met Luther personally. The only possible meeting was prevented by Philipp Melanchthon, who did not pass on a letter addressed to Luther, that Calvin wrote in January 1545, regarding a meeting. They seldomly mentioned each other in their writings. One should also remember that Calvin understood no German and Luther no French, and it is therefore evident that the two of them would probably never have had a close personal relationship (Selderhuis, 2008:57-58). In spite of this, Calvin called the 26 year older Luther "brother" and "father" (Ganoczy, 2004:15).

Calvin had a big appreciation for Luther. In fact, it was Luther's theology, especially his two Catechisms as well as his treatises on The freedom of the Christian and The Babylonian captivity, that inspired the first edition of his Christianae religionis institutio (Ganoczy, 2004:9). During the time of the Eucharistic controversy, he stated that he personally felt closer to Luther than Zwingli. He was not prepared to compare Luther to Elijah, but stated that "the gospel came forth from Wittenberg". In the foreword to his commentary to the Romans, Calvin said that he hoped what he had written, would be pleasing to Luther. Luther, on the other hand, informed Calvin via Bucer, that he had read his books with enjoyment. It is known that Luther had at least read Calvin's Supplex exhortatio ad caesarem (1543) and the Latin translation of his Treatise on the Eucharist (1549) (Vera christianae pacificationis et ecclesiae reformandae ratio; cf. De Groot, 1953; Selderhuis, 2008:58-59). According to an anonymous witness, shortly before his death, Luther praised this treatise as the work of a learned man, pious and trustworthy in matters of faith (Ganoczy, 2004:15).

In spite of the mutual appreciation they had for one another, they also disagreed on certain points, but without destroying their bond of unity. These two has shown us that, although one could disagree on certain issues, there could still be a strong bond of unity. From this relationship one should learn that the freedom to disagree with others, even criticising them, should not necessarily endanger the bond of unity. Calvin had a tremendous admiration for Luther and felt him one with the latter. However, he never became enslaved to him - he even stated this in a letter to Bullinger on 21 January 1549. This freedom allowed him, for instance, to criticise Luther's hermeneutics and his lack of historical knowledge concerning the prophets. Calvin respected Luther's views on the Lord's Supper, but was of the opinion that his unwillingness to compromise and his insistence that only his view should triumph, presented a danger to 
the unity of the church. In his letter of 12 January 1538 to Bucer, he praised Luther's piety, but complained about his stubbornness concerning the Eucharist debate (Selderhuis, 2008:60). One could therefore understand that Calvin's initial hesitance concerning the Wittenberg Concord (1536), was mainly due to Luther's viewpoint on the Eucharist, but it is ecumenically and educationally important to note that after his meeting with other Lutherans, for instance at the Imperial Diet at Worms (1539), he eventually accepted the Confessio Augustana (CA) (1530) 1 in 1548 and the Confessio Augustana Variata during the religious colloquies in Regensburg (Selderhuis, 2008:59-60). His freedom to disagree on smaller theological points, while willing to look for consensus and unity at all cost was an important principal that has validity to this day.

\subsection{Calvin and the Lutherans}

It is ecumenically noteworthy that the much younger Calvin, who had no close personal relationship with Luther, had a warm-hearted relationship with many Lutherans in Wittenberg, for instance with Philipp Melanchthon. On 16 February 1543 he wrote a letter to Melanchthon in which he complained about the big distance between Geneva and Wittenberg. However, he comforted both with the assurance that one day, they would be together in heaven forever (cf. Selderhuis, 2008:57, 60-61). His foreword $\mathbf{2}$ in the French edition (1546) of Melanchthon's Loci communes (1545) is a sign of his association with the man from Wittenberg. He never made critical remarks about this work, although he did not agree with everything Melanchthon had published. For instance, he had critical remarks on his understanding of predestination. He believed that Melanchthon argued more like a philosopher, and not as a biblical scholar on this matter (De Greef, 1989:188). Calvin and Melanchthon also had different opinions on the status of the liturgy. Melanchthon accepted the Statement of Leipzig (21 December 1548) in which liturgical matters were viewed as adiaphora. Calvin disagreed and supported the critique of Flacius Illyricus on the statement, namely that liturgical matters were not unchangeable dogmas, but

1 Although the CA was written by Melanchthon, the content is typical Lutheran. There is general consensus on the fact that Luther and his theological views paved the way for the CA (cf. Concordia, 2005:53-56).

2 Calvin promoted unity among the protestants in this unique way of writing forewords in books of others, such as Henri Scrimger (1550) and Gabriel de Saconay (1561) (cf. De Greef, 1989:188-190). 
still important aspects of faith (cf. Selderhuis, 2008:61). In spite of these disagreements, the two remained close friends, and united on the main topics of the Reformation. The relationship between Calvin and Melanchthon can serve as an example to us all, on how to avoid unnecessary conflict, while maintaining and improving ecumenical relationships. When Melanchthon refused to give Calvin's request for a discussion to Luther, his motive had been to prevent any further conflict between Wittenberg and Switzerland. When Luther aggressively attacked the liturgy of Zurich, Calvin requested Melanchthon in a letter on 21 April 1544 to calm Luther down and try to convince him of a more tolerant approach to matters concerning the liturgy (cf. Selderhuis, 2008: 60).

Unfortunately, Calvin's relationship to the (other) Lutherans did not portray this same spirit of unity. Calvin believed that he was a true exponent of Luther's biblical insights. He ascribed his conflict with the Lutherans to their un-Lutherlike theology. He accused them of disturbing the unity between the reformational groupings, because they radicalised the question of Christ's presence in Holy Communion, whilst Luther himself - according to Calvin - later viewed this question as secondary. Calvin devoted his commentary on Genesis (1554) to Johannes Friedrich of Saxony. The Lutherans unfortunately prevented this tribute due to Calvin's views on the Holy Communion. In 1555 Calvin stated that, should Luther have lived, he would not have identified with these Lutherans (cf. Oberman, 1988:232-245; Selderhuis, 2008:61-62 in support of this statement).

The unity between the German Lutherans and the Swiss reformational groups was blown away, especially by Joachim Westphal of Hamburg. He reacted extremely harsh against the Swiss Consensus Tigurinus. In 1552 Westphal rejected the Calvinistic ${ }^{3}$ understanding of the sacrament as a human invention. Calvin answered with a defence-publication in 1555 (Defensio sanae et orthodoxae doctrinae de sacramentis) that started a stream of anti-Calvinistic publications from the Lutherans. This conflict eventually affected the Dutchspeaking reformed refugee congregation in Frankfurt. Westphal influenced the Lutheran ministers negatively, convincing them that there was no unity in teaching and liturgy between the reformed and Lutheran groups using the same church building. As a result, the congregation was forced in 1561 to stop functioning as a separate congregation whilst using the Lutheran church building. The con-

3 He was the first person who used the term Calvinism. 
gregants then sought advice from Calvin in regard to their participation in Holy Communion in the Lutheran congregation. He recommended that they partake in the Lutheran celebration, because it did not matter who the person was who served the bread and wine. Although he saw the ritual as important, he did not see it as essential. As long as they were not to be forced to accept the Lutheran understanding of Holy Communion, they should - for the sake of unity - not distance themselves from the congregation in Frankfurt. This was the same advice he gave to the congregation of Wesel in 1533, when confronted with a similar dilemma. Unification with the Lutherans was, therefore, regarded by Calvin to be a far better option than the disappearance of a reformed congregation.

In spite of all the negativity experienced from some of his Lutheran brethren, Calvin enjoyed longstanding and good relationships with many other Lutherans. In 1540, he wrote that he regarded unity with the Lutherans as one of his priorities in life. Until his death he was of no other opinion. Not even the unjustified polemics of some Lutherans could change his mind (cf. Selderhuis, 2008:62-63). He remained committed to the unity of the Reformation until his death.

\section{Luther and the unity of the church}

Luther will certainly not go down in history as an eirenicist. He was involved in a number of controversies, with Erasmus, Karlstadt, Müntzer, Anabaptists, Spiritualists, Zwingli, Bullinger and innumerable Roman opponents. It is therefore not surprising that some scholars cannot view Luther as a well-defined ecumenical personality who committed himself to efforts towards unity (Nijenhuis, 1994: 42).

In a certain way, Luther should be blamed (although not alone) for the schisms within the Reformation. His opinions of other reformers, and the way in which he conveyed it, were unacceptable, and it is, therefore, understandable that they were unwilling to walk the extra mile with him. The first colloquy designed to bring about unity among the protestant churches was that of Marburg, 1529. In spite of Oecolampadius' good theological intent, Luther regarded it as an abomination to sit around a table with sectarians (Schwärmer - as he regarded the Zurichers). At the end of the negotiations with Bucer 
and Zwingli he remarked: "you have a different spirit from us". 4 It is disappointing that Luther referred to his fellow reformers in this way, especially in the light of the fact that they had agreed on fourteen aspects of the faith while disagreeing only on one aspect, namely the Lord's Supper. Luther continued with his personal attacks on Zwingli even after the Wittenberg Accord of May 1536, signed by Bucer, Capito, Melanchthon and himself. In 1539, he called Zwingli a "Nestorian" in his Von den Konzilien und Kirchen. In 1541, he called him, together with Müntzer, "sectarians and heretics" in his Vermahnung zum Gebet wider den Turken, and in September 1544 he totally lost control in Ein kurzes Bekenntnis von heiligen Sakrament, by making opprobrious remarks about the Swiss reformers. Such utterances drove a wedge between reformed and Lutheran churches (cf. Nijenhuis, 1994:42-44).

Clearly, Luther cannot be described as the father of the ecumenical movement, but this does not mean that he deliberately undermined the confession concerning the oneness and catholicity of the church. From the little he wrote $\mathbf{5}$ on this theme, it is clear that he regarded the unity of the church as very important, although not as his prime consideration (cf, Lohse, 1988; Bayer, 2003:235-255). He did not even think about the church in plural terms. His main concern was the true church and not the one church. The true church to Luther was a "spiritual assembly of souls in one faith". The concept of the church was not cognate with the visible institutional connection with Rome. Within the framework of his spiritual understanding of Christianity, he stated that "Christendom means an assembly of all on earth who are Christian believers"; it embraces all who live in the right faith, hope and love. It was not a "visible assembly, but an assembly of hearts in one faith, united by the Holy Spirit the world over". Luther consequently did not translate communio sanctorum as the "community of saints", but as the "flock of saints". He once wrote:

$4 \quad$ His words "Ihr habt einen anderen Geist als wir" does, however, not mean that you are evil-minded people, as some scholars would like to translate (cf. Nijenhuis, 1994:42 especially footnote 81).

Luther left us no systematic exposition of ecclesiology and, therefore, no comprehensive treatise on the unity of the church. There are two reasons for this. Firstly, he found no such ecclesiology in the theological tradition. The important works of the Scholastics recognised no locus de ecclesia. Secondly, Luther himself was no systematic theologian. The only more or less systematic statement on the different loci is to be found in his Large Catechism (1529) and the Schmalkaldic Articles (1537-1538) (cf. Lohse, 1995:295). 
I believe that there is a holy little flock and community on earth made up only of saints under one Head ... called together by the Holy Spirit in one faith, mind and understanding, with all manner of gifts, yet united in love, without sects or divisions. (Nijenhuis, 1994:28-31; WA VI, 292-296.)

The church, the small gathering of believers, was constituted by listening to and accepting the preaching of the Word - the Word of justification by faith alone. When the Word was preached everywhere according to Scripture, then there would be unity. For this reason, Luther was in favour of a "protestant office of bishop". 6 The bishop would secure true, biblical preaching, and in this way, enhance unity among the believers (Lohse, 1995:296). Luther did not understand church unity as a matter of faith alone, but also as oneness in love. He interpreted communio sanctorum also as the community of saints, and this meant a community which accepted its diaconal responsibilities towards its members (cf. Peters, 1991:215229; Lohse, 1995:297; Van Wyk, 1995).

Although Luther understood church and the unity of the church spiritually, he also regarded the church as a social construction. The church was the "new people (volk) of God". According to him, "God's Word cannot be without God's people, and God's people cannot be without God's Word" (WA 11,408,8-10 - The Christian gathering of 1523). God's people could be recognised by the markings of a true church. When all believers and all congregations could be linked to these notae ecclesiae, 7 then there would be growth in unity. Church unity, according to Luther, was therefore also a matter of authentic Christian living.

Unfortunately, Luther also believed that unity was unity in teaching, with the expectation that a $100 \%$ agreement on the formulation of

6 Calvin agreed with Luther that the office was constitutive for church unity. He was therefore willing to accept the idea of a "Lutheran bishop" (cf. Kühn, 1980:65-68). 
creedal matters had to be reached before one could speak of unity between groups. His unwillingness to live with a $97 \%$ consensus, kept Lutherans and Calvinists apart up to the latter part of the twentieth century. 8

\section{Calvin and the unity of the church}

John Calvin worked tirelessly for the unity of the church. He rejected all forms of schisms (cf. Niesel, 1938:187-188). His systematic explications of the unity of the church (Inst. 4,1.1-2; cf. Ganoczy, 1968; Nijenhuis, 1994:35-40; Plasger, 2008a:109-111 for detailed information) form only a small part of his massive contribution in this regard. His pastoral and theological advices to hundreds of people in other countries, his accommodation of hundreds of students from all over Europe, his willingness to seek ecumenical consensus on theological matters and his friendship with leaders from various churches are better indications of his valuable contribution in this regard. It is therefore important to look at his contribution to the unity of the church from different angles and perspectives.

\subsection{Calvin and the unity of the church in Geneva}

Calvin understood that church unity started and ended with the unity in the congregation and between congregations. The basic prerequisite for unity in the local congregation is a common confession and church order. As early as 1536, Calvin composed a confession of faith (confessio fidei) and laid down rules for a monthly celebration of the Lord's Supper (Ganoczy, 2004:11). After his return to Geneva in 1541 he compiled a catechism (1542) and wrote the Ecclesiastical ordinances that created order and unity among the protestants. However, Calvin also knew that unity would only become a reality when the institutionalised rituals of the congregation were supported by other religious activities during the week. In Geneva, the bonds of unity were strengthened by the Company of pastors (Compagnie des pasteurs), which held a weekly Bible study (Congrégations), discussed pastoral problems and brotherly assessed one another every three months. The work of the elders and deacons that Calvin enthusiastically developed, also contributed to the unity of the church as well as unity among the members of society. One should not underestimate the diaconal activities in Geneva as instruments of

8 Unity with the Confessional Lutheran Churches is therefore also not possible today (cf. Marquart, 1990:41-77). 
unity among believers, congregations and the public. Calvin's efforts to provide food for the thousands of hungry people in Geneva, not only gave the Reformed movement a good name, but also convinced the citizens to unite around people of moral integrity (cf. Olson, 2004:163-167).

\subsection{Calvinus oecumenicus}

Calvin understood church unity as something that was also way beyond the unity of the local church. He understood church unity as the unity between Christians and congregations all over the world. $\mathrm{He}$ expressed this understanding of unity, inter alia, in a pastoral way by the writing of letters. He wrote no less than 8500 letters to people in a myriad of countries. In 1563 his secretary, Charles Jonvillier, noted that the burden of letter-writing had brought him to the verge of collapse. Calvin wrote these thousands of letters as an opportunity to promote the reformed protestantism and to enhance unity among the reformational groups. One category of letters that deserves special mention is his letters to martyrs. These letters were not private letters, but circulars. The prisoners circulated it in the prisons as sources of spiritual inspiration and support. These letters, as well as the letters to the refugee congregations, are statues of Calvin's ecumenical mind and his devotion to the unity of the church (cf. Nijenhuis, 1959; Van Veen \& Van Stam, 2008:212-221). Calvin wrote his most famous words on church unity in a letter to Thomas Cranmer, the Archbishop of Canterbury, in 1552. When Cranmer was planning to convene an evangelical council to create unity among the reformational groupings, Calvin said that he would cross ten seas to ensure the success of such an idea (De Greef, 1989: 199). The best way, therefore, to pay homage to Calvin, is by calling him Calvinus oecumenicus (Nijenhuis, 1959).

It is important to remind South Africans, as people who have been isolated for long periods throughout history, and who have sadly developed a "laager mentality", 9 of Calvin's ecumenical work in Eastern Europe. He had contact with students, theologians, church leaders and politicians in Poland-Lithuania and Hungary as well as with the Bohemian Brethren (Böhmische Brüder) in the present-day Czech Republic. Calvin advised them on theological and church matters and showed interest in their personal well-being. His pas-

9 This is a South African word meaning the urge to and satisfaction of a life in isolation due to fear of outsiders and strangers. 
toral involvement in the private, religious and political lives of people, who shared the same theological convictions as he did, although separated from him by vast distances, is an important aspect of church unity. Only those who are willing to emulate Calvin in this regard could claim to following him in his understanding of the oneness of the church. Calvin teaches us that a church, clergy and theologians, who are pastorally busy only with their own concerns, cannot confess on a Sunday that they "believe in the one, catholic church" (cf. Mühling, 2008:96-104 for an overview of his assistance to the reformed believers in Eastern Europe).

Calvin's ecumenical mind that was grounded in his belief in the oneness of the church, led to his consensus-seeking approach in matters of importance. A good, but mostly unknown example of his consensus-seeking mind, relates to the death penalty he had ordered for the heretic Michaelus Servetus in 1553. The journalistic view exists that Calvin was solely responsible for this deed and that this deed would remain to be an eternal indictment against his integrity (cf. Selderhuis, 2008:2-4). The fact of the matter is that he consulted widely on this matter and quickly obtained the support of the believing communities of Zurich, Berne, Basle and Schaffhausen. Bullinger and Haller emphatically sanctioned the death penalty of Servetus from the start. Melanchthon (the "Lutheran"), however, was hesitant at first, but subsequently agreed as well. They all agreed, not because they were evil-minded people, but because their cultural and educational environment, which was characterised by the absence of religious tolerance, expected them to act in this way (Neuser, 1971:79-80; Ganoczy, 2004:18). What is important here is the fact that Calvin made his decision after ecumenical consultation. He did not act alone. He searched for ecumenical agreement on matters. The fact that he did not proceed with this matter before he got the assent of Melanchthon, underlines his ecumenical sensitivity and commitment to a united protestantism.

Calvin's ecumenical concerns and sense of unity with others under persecution can be explained by means of his status as a refugee. His displacement played an important role in his theological thinking and ecclesiastical work. As someone with a lost identity and no permanent place of residence, he identified with others who lived in danger and uncertainty (Vosloo, 2009). It is understandable that his existence as a refugee turned him into a personality with a sense of ecumenical responsibility. 
Nowhere does his sense of ecumenical responsibility become more clear than through his work in the fields of education and training. The erection of his Academy on 5 June 1559, with Theodore Beza as the first rector, contributed enormously to church unity on the local level as well as ecumenically. Thousands of children and students came from all over Europe to study at the Academy. This Academy provided education on two levels. The first level was a private school (schola privata) where children could first learn to read and write and then receive instruction in Latin, Greek and philosophy. The second level was a public school (schola publica) where students could continue with their studies at university level in theology, law and medicine (Ganoczy, 2004:19-20). Many international exchange programs were initiated for both the school and the university. These exchange programs did not only concentrate on contact between those from the reformed background, but also between the Calvinists and the Lutherans. It is important to mention again at this point the relationship between Calvin and Melanchthon. These two shared in the ideal of a broad humanistic education. Both of them were educated in the classics, law and medicine. The enormity of their intellectual legacies did not bind Geneva and Wittenberg alone, but also others, all over Europe and eventually the world, who appreciated the intellectual and educational aspirations of the two learned men (cf. Ehrenpreis, 2008:422-431).

It should be self-evident that the men who transformed the academic landscape, contributed to the methodological approaches of (at least) theology. Calvin's theological methodology (which he shared with Melanchthon) made unity possible between many theologians from various contexts. Calvin did not leave us with one, exclusive orthodox system. His theology, as well as the theology of those who followed him, was pluriform of origin and eclectic with regard to its sources. Calvin can be identified with the ongoing Western trinitarian and anti-Pelagian tradition. This tradition draws its theology from the broad Western intellectual tradition, consisting of patristic, Medieval, Renaissance and reformational perspectives. Calvin's concentration on exegesis, philology, philosophy, law, medicine and context, puts his theology within the framework of a universal intellectual education. His inclusive approach to intellectual traditions, his openness to other insights and his tolerance of the truths of other sciences ensured a truly ecumenical theology (Trueman, 2004:239-240). This theological methodology makes unity in diversity possible - an approach that could bring churches together without forcing them together in one structure. 
Many see John Calvin, and rightly so, as the father of the ecumenical movement (Ganoczy, 2004:21). His catholic understanding of the one church of Christ and his outreaching pastoral relationship to churches all over Europe, laid the foundation for the ecumenical movements and organisations of later centuries. Calvin's ecumenical mind was shaped by his belief in the unity and catholicity of the church, his struggle against idols (grounded in the first two commandments), his willingness to engage with churches of other traditions, his shaping of a multinational and multicultural Geneva, and his vision to promote a lifestyle of love and deaconship all over Europe (Douglass, 2004:306-311). Many heirs to his thought have been active leaders in the modern ecumenical movement, believing that Calvin's theology supports their work (Douglass, 2004:305). One can only hope that the legacy of the Calvinus oecumenicus will sooner or later also grasp the mainline reformed churches in South Africa. Our unwillingness to commit to activities that could serve the ideal of unity does not portray a Calvinistic spirit.

\subsection{Calvin's contribution to the controversies on the Lord's Supper 10}

Calvin (like the other reformers) understood church unity as unity in the truth of the gospel and, therefore, as unity in teaching, which includes the teaching on the Lord's Supper. Unfortunately, this was the very matter that drove Lutherans and reformed believers apart. The scope and length of this article allow only for a few remarks on Calvin's role in this episode.

During the time of the Eucharistic controversy, Calvin stood out as the person who mediated between the German Lutherans and the leaders of the Swiss Reformation. He worked tirelessly to ensure unity among the Reformational groups. He endeavoured to convince people on both sides of the conflict to look for consensus. He was the person who proposed the method of compromise to the conflicting parties. His acquiescence, even in matters of the correct teaching, distinguished him from the other reformers as the man who regarded unity much more important than the triumph of particular dogmatic convictions. He refused to side with either Luther or Zwingli. He believed that they could come to a reasonable and acceptable agreement that would keep the protestant movement

10 Cf. Neuser (1971:84-88), De Greef (1989:169-178), and Gamble (2004:193196) for short but comprehensive information on this matter. 
together. Tolerance of minor differences, was regarded by him as essential in the strife for unity.

Calvin failed to successfully mediate between the Germans and the Swiss, but he had success with the reformed fractions in Switzerland. The Consensus Tigurinus of May 1549 is a statue to Calvin's conscience regarding church unity.

Why was it possible for Calvin to play the role of mediator? Which aspects of his theology prepared and equipped him for this role? Firstly, his ecclesiology (cf. Plasger, 2008a:107-115; 2008b for an overview). His understanding of the church as the community of elect, as the community that is grounded in the universal covenant, guided him to the realisation that unity was a moral and pastoral duty. The community of elect should do everything possible to join together around the Table of the Lord! Secondly, his exegetical methods and his hermeneutics (cf. Thompson, 2004) made it possible to read Matthew 26:28 not in a biblisistic way. His advanced exegetical and hermeneutical methodology made it possible to deal with Scripture in such a way that the possibility of accommodation, tolerance and consensus would become a reality.

\section{Conclusion}

Unfortunately, Luther and Calvin were not in a position to join hands and minds in efforts to promote unity among reformational groups. In spite of this, both of them realised the importance of a united church. Luther did what was possible as the leader of the "first Reformation" - the reformation of the monasteries. Calvin, as the leader of the "third Reformation" - the reformation of the refugees (cf. Oberman, 2003 for this terminology) - did more than what was expected of him. The fact that he was a stranger in a foreign city was an important reason why he became the most exemplary figure in matters that concerned the unity of the church. Calvin should be honoured as the man who showed us, even today, how we could work together as people who are one in Christ and with each other.

\section{List of references}

BALKE, W. 1982. Calvijn en Luther. (In Graafland, C., Kamphuis, J., Van 't Spijker, W. \& Exalto, K., reds. Luther en die gereformeerd Protestantisme. 's Gravenhage: Boekencentrum. p. 99-117.)

BAYER, O. 2003. Martin Luthers Theologie: eine Vergegenwärtigung. Tübingen: Mohr.

CALVIN, J 1989. Calvin's Institutes: a new compend. Ed. by H.T. Kerr. Kentucky: John Knox. 
CONCORDIA. 2005. The Lutheran Confessions: a reader's edition of the book of Concord. Based on the translation by W. Herrmann, T. Dau \& G. Bente. Revised, updated and annotated by McCain and others Saint Louis: Concordia Publishing House.

DE GREEF, W. 1989. Johannes Calvijn: zijn werken en geschriften. Kampen: De Groot Goudriaan.

DE GROOT, D. 1953. Om de eenheid en vrede der kerk: Johannes Calvijns geschrift Vera christianae pacificationis et ecclesiae reformandae ratio. Uit Latyn vert. door D. De Groot. Amsterdam: Van Bottenberg.

DOUGLASS, J. 2004. Calvin in ecumenical context. (In McKim, D., ed. The Cambridge companion to John Calvin. Cambridge: Cambridge University Press. p. 305-316.)

EHRENPREIS, S. 2008. Calvin - Bildung and Pädagogik. (In Selderhuis, H., Hrsg. Calvin Handbuch. Tübingen: Mohr. S. 423-431.)

GAMBLE, R. 2004. Calvin's controversies. (In McKim, D., ed. The Cambridge Companion to John Calvin. Cambridge: Cambridge University Press. p. 188-2003.)

GANOCZY, A. 1968. Ecclesia Ministrans: dienende Kirche und kirchlicher Dienst bei Calvin. Freiburg: Herder.

GANOCZY, A. 2004. Calvin's life. (In McKim, D. ed. The Cambridge companion to John Calvin. Cambridge: Cambridge University Press. p. 3-24.)

INST.

see CALVIN, 1989

KÜHN, U. 1980. Kirche. Gütersloh: Mohn. (HST 10.)

LOHSE, B. 1988. Die Einheit der Kirche bei Luther. (In Lohse, B., Hrsg. Evangelium in der Geschichte: Studien zu Luther und der Reformation. Göttingen: Vandenhoeck. S. 300-314.)

LOHSE, B. 1995. Luthers Theologie in ihrer historischen Entwicklung und in ihrem systematischen Zusammenhang. Göttingen: Vandenhoeck.

LUTHER, M. 1883. Luthers Werke: kritische Gesamtausgabe. Hrsg. J. Knaake et al. (Weimarer Ausgabe.)

MARQUART, K. 1990. The church and her fellowship, ministry, and governance. St. Louis: The Luther Academy. (Confessional Lutheran Dogmatics, vol. 9.)

MÜHLING, A. 2008. Calvin und Osteuropa. (In Selderhuis, H., Hrsg. Calvin Handbuch. Tübingen: Mohr. S. 96-104.)

NEUSER, W. 1971. Calvin. Berlin: De Gruyter. (Sammlung Göschen, Band 3005.)

NIESEL, W. 1938. Die Theologie Calvins. München: Kaiser.

NIJENHUIS, W. 1959. Calvinus Oecumenicus: Calvijn en de eenheid der kerk in het licht van zijn briefwisseling. 's Gravenhage: Nijhoff. (Kerkhistorische Studien, deel 8.)

NIJENHUIS, W. 1994. Church unity in Luther and Calvin. (In Ecclesia reformata: studies on the reformation. Vol. 2, dl. 16. Leiden: Brill. p. 2447.)

OBERMAN, H. 1988. Luther: mens tussen God en duivel. Uit Duits vert. deur C. den Heyer. Kampen: Kok.

OBERMAN, H. 2003. The two reformations. New Haven: Yale University Press.

OLSEN, J. 2004. Calvin and social-ethical issues. (In McKim, D., ed. The Cambridge companion to John Calvin. Cambridge: Cambridge University Press. p. 153-172.) 
PETERS, A. 1991. Kommentar zu Luthers Katechismen. Band 2: Der Glaube das Apostolikum. Hrsg. von G. Seebaß. Göttingen: Vandenhoeck.

PLASGER, G. 2008a. Johannes Calvins Theologie: eine Einführung. Göttingen: Vandenhoeck.

PLASGER, G. 2008b. Kirche. (In Selderhuis, H., Hrsg. Calvin Handbuch. Tübingen: Mohr. S. 317-325.)

SELDERHUIS, H. 2008. Calvin und Wittenberg. (In Selderhuis, H., Hrsg. 2008. Calvin Handbuch. Tübingen: Mohr. S. 2-4, 57-63.)

SMIDT, U. 1972. Zur Einheit der Kirche. (In Smidt, U. Johannes Calvin und die Kirche: ein Lesebuch mit Texten und Themen. Stuttgart: Evangelisches Verlagswerk. S.12-17.)

THOMPSON, J. 2004. Calvin as biblical interpreter. (In McKim, D., ed. 2004. The Cambridge companion to John Calvin. Cambridge: Cambridge University Press. p. 58-73.)

TRUEMAN, C. 2004. Calvin and Calvinism. (In McKim, D., ed. 2004. The Cambridge companion to John Calvin. Cambridge: Cambridge University Press. p. 225-244.)

VAN VEEN, M. \& VAN STAM, F. 2008. Calvin - Werke: Briefe. (In Selderhuis, H., Hrsg. 2008. Calvin Handbuch. Tübingen: Mohr. S. 212-221.)

VAN WYK, I.W.C. 1995. Die gemeenskap van die heiliges. Hervormde teologiese studies, 51(3):732-752.

VOSLOO, R. 2009. The displaced Calvin: "Refugee reality" as a lens to reexamine Calvin's life, theology and legacy. Religion \& theology, 16(1 \& 2):35-52.

WA

see LUTHER, M.

WARC

see WORLD ALLIANCE OF REFORMED CHURCHES

WORLD ALLIANCE OF REFORMED CHURCHES. 2007. What is the significance of Calvin's legacy? Reformed world, 57(4):231-236.

\section{Key concepts:}

Calvin

church unity

ecclesiology

Holy Communion

Luther

\section{Kernbegrippe:}

Calvyn

ekklesiologie

kerkeenheid

Luther

Nagmaal 
